\title{
Ovulatory response and embryo quality in Katahdin ewes supplemented with palm oil
}

\author{
S. Torres-Zapata ${ }^{1}$, C. Luna-Palomera ${ }^{1 \#}$, J.A. Aguilar-Cabrales ${ }^{1}$, J.A. Peralta-Torres $^{1}$, \\ J.R. Aké-López ${ }^{2}$, F. Sánchez-Dávila ${ }^{3}$ \& J. Abad-Zavaleta ${ }^{4}$ \\ ${ }^{1}$ Laboratorio de Reproducción y Genética Animal, División Académica de Ciencias Agropecuarias, \\ Universidad Juárez Autónoma de Tabasco, México \\ ${ }^{2}$ Facultad de Medicina Veterinaria y Zootecnia, Campus de Ciencias Biológicas y Agropecuarias, \\ Universidad Autónoma de Yucatán, México \\ ${ }^{3}$ Facultad de Agronomía, Universidad Autónoma de Nuevo León, México \\ ${ }^{4}$ Instituto de Biotecnología, Universidad del Papaloapan, Campus Tuxtepec, Oaxaca, México
}

(Received 21 March 2015; Accepted 20 April 2016; First published online 17 August 2016)

Copyright resides with the authors in terms of the Creative Commons Attribution 2.5 South African Licence.

See: http://creativecommons.org/licenses/by/2.5/za

Condition of use: The user may copy, distribute, transmit and adapt the work, but must recognise the authors and the South African Journal of Animal Science.

\begin{abstract}
The aims of this study were to evaluate the superovulatory response (SR), embryo quality and embryonic development in Katahdin ewes that received a dietary supplement of palm oil (PO). Ten ewes were assigned to receive $35 \mathrm{~g}$ palm oil $(n=10$, PO3) and 10 to receive $70 \mathrm{~g}$ palm oil $(n=10$, PO6) for 25 days. On day 0 , the ewes were synchronized with $0.3 \mathrm{mg}$ progesterone-releasing devices (CIDR-G ${ }^{\circledR}$ ). From days 6 to 9 , the donors were superovulated with $200 \mathrm{mg}$ follicle-stimulating hormone (FSH) (Folltropin- $\left.V^{\circledR}\right)$ at decreasing doses every 12 hours ( $40-40,30-30,20-20$ and $10-10 \mathrm{mg} / \mathrm{ewe}$ ). On day 8, the devices were removed and donors were mated twice with fertile rams at 12-h intervals. Seven days after mating, the embryos were recovered and evaluated for their stage of development and quality grade $(1=$ excellent, $2=$ good, $3=$ bad and $4=$ degenerated). In addition, on days 0,7 and 15 , blood samples were taken to determine cholesterol, triglycerides, insulin and insulin-like growth factor-1 (IGF-1) concentrations in serum blood. Using chi-square and t-tests, the superovulatory response (SR), ovulation rate (OR), total embryonic structures (TES), transferable embryos (TE), degenerated embryos (DEs) and developmental stage and quality were evaluated. No significant differences were observed between treatments for SR, OR, TES and TE variables or for cholesterol, triglycerides, insulin and IGF-1 concentrations. There were differences in the numbers of DE, as well as a trend for more homogeneous developmental stage in the embryos of ewes supplemented with PO6, as well as a higher number of quality 1 embryos and lower numbers of quality 3 and 4 embryos. Palm oil supplementation could be a recommendable practice to improve the quality of embryos and homogenous developmental stage (morula and blastocyst).
\end{abstract}

Keywords: Fatty acids, ovarian activity, sheep

\# Corresponding author: carlos.luna@ujat.mx

\section{Introduction}

The inclusion of vegetable fats in supplements for cattle and sheep feeding improves the energy balance and bioavailability of fatty acids for the synthesis of cholesterol, eicosanoids and steroid hormones. These metabolites have a number of functions in ovarian and uterine activity, and have been shown to have a positive influence in the reproductive performance of sheep and cattle (Mattos et al., 2000; Santos et al., 2008). Concentration of selenium in follicle population and diameter increased in dairy cattle when the dietary energy density was increased (Gwazdauskas et al., 2000; Marei et al., 2009; Renaville et al., 2010). Also, increases in diameter, higher numbers and quality of oocyte and larger sizes of the corpus luteum (CL) and gonadotropin secretion of the dominant follicle have been observed in sheep (Mattos et al., 2000; Boland et al., 2001; Marei et al., 2010). The supplementation of diets with corn oil, which is rich in polyunsaturated fatty acids (PUFAs) resulted in a higher number of $\mathrm{CL}$ and embryos being collected in Pelibuey sheep that underwent superovulatory treatment (Herrera-Camacho et al., 2008). Moreover, some studies have reported that fat supplementation in ruminants causes high blood cholesterol level (COL), highdensity lipoproteins and low-density lipoproteins (Espinoza et al., 2008). These metabolites are the main precursors of COL for the synthesis of steroid hormones (Whates et al., 2007; Manna et al., 2009), hence 
contributing to improving the development of follicles and the steroid hormone-synthesizing capacity of the ovaries. Thus, it is important to determine the way in which the metabolism of vegetable fats relates to the ovarian response and quality of embryos in ewes.

The benefits to ovarian function, quality, number and size of the follicles of including a PUFA diet have been documented (Wonnacot et al., 2010; Meza- Villalvazo et al., 2013). Their effects in prostaglandins and steroid biosynthesis are mediated by alterations in the uterus gene expression, which in turn promotes development and embryo implantation (Wonnacot et al., 2010; Hughes et al., 2011; Waters et al., 2012).

In tropical regions there are diverse sources of feedstuffs rich in fatty acids (Velázquez \& Gómez, 2010), such as oil extracted from the kernel of the African palm (Elaeis guineensis), which exhibits an approximate content of $51 \%$ unsaturated fatty acids and $49 \%$ saturated fatty acids. Since the effectiveness of crude palm oil (PO) in the reproductive activity of ruminants has not been proven (Trujillo-Castillo et al., 2010), it is worth evaluating its potential in ewes that are intended for multiple ovulation and embryo transfer. The objectives of the present study were therefore to evaluate the SR, embryo quality grade and embryonic developmental stage, and their relation to certain lipid, insulin and IGF-1 metabolites in hair ewes whose feed has been supplemented with palm oil.

\section{Materials and Methods}

The study was conducted from February to March 2014 (out-of-season breeding) in the municipality of Cunduacan, Tabasco, Mexico, which is located at $18^{\circ} 04^{\prime} 06.69720^{\prime \prime} \mathrm{N},-93^{\circ} 10^{\prime} 55.18200^{\prime \prime} \mathrm{W}$. In this region, a wet tropical climate prevails, with abundant rainfall in summer Am(w) (Garcia, 2004). The annual average temperature is $26^{\circ} \mathrm{C}$, with mean annual precipitation of $2643 \mathrm{~mm}$ (INEGI, 2010). Under this premise, which was a completely randomized design, 20 Katahdin donors were used. The ewes were assigned to two groups: PO3 ( $n=10 ; 54.20 \pm 1.92$ kg; 3.9 body condition); and PO6 ( $n=10,53.8 \pm 2.87$ kg; 3.85 body condition). Taking $1.1 \%$ dry matter intake as the base in maintenance (NRC, 1985), the ewes in PO3 received 3\% (35 g) and those in PO6 received 6\% (70 g) crude PO. The oil was mixed daily in a $500 \mathrm{~g} / \mathrm{ewe} / \mathrm{d}$ supplement containing $10.46 \mathrm{MJ} / \mathrm{kg}$ metabolizable energy (ME) and $135 \mathrm{~g}$ crude protein $/ \mathrm{kg}$. The conditioning period was eight days and the evaluation period 25 days. The superiority of treatments that include vegetable fats over a control group is evident, so a control group was not included in this study.

The ewes remained confined, with maize silage and water ad libitum. The handling procedures were conducted according to the Mexican Official Standard 051-ZOO-1995 guideline for humane handling and in accordance with the Mexican official standard of technical specifications for the production, care and use of experimental animals.

Reproductive performance evaluation in donor ewes included the superovulatory response (SR) (number of $\mathrm{CL}$ present in the ovaries), number of embryonic structures recovered, quality and embryo development stage. The donors underwent the following oestrous synchronization and superovulatory protocol: On day 0 , the donors were synchronized with a short protocol, which included an intravaginal progesterone-releasing $(0.3 \mathrm{mg})$ device (CIDR-G ${ }^{\circledR}$, Pfizer, Hamilton, New Zealand), which was removed eight days after application (7:00). At intravaginal-device removal, $75 \mu \mathrm{g} \mathrm{IM} \mathrm{D-cloprostenol} \mathrm{(Sincroprost,} \mathrm{Bio-Zoo,}$ Mexico) was applied. The donors were superovulated at a total dose of $200 \mathrm{mg} \mathrm{FSH}$ (Folltropin- $V^{\circledR}$ Bioniche Animal Health, Ireland), administered at decreasing doses every 12 hours at 06:00 and 18:00 (40 - 40, 30 30, 20 - 20 and $10-10 \mathrm{mg} / \mathrm{ewe}$ ), according to the manufacturer's protocol (Figure 1).

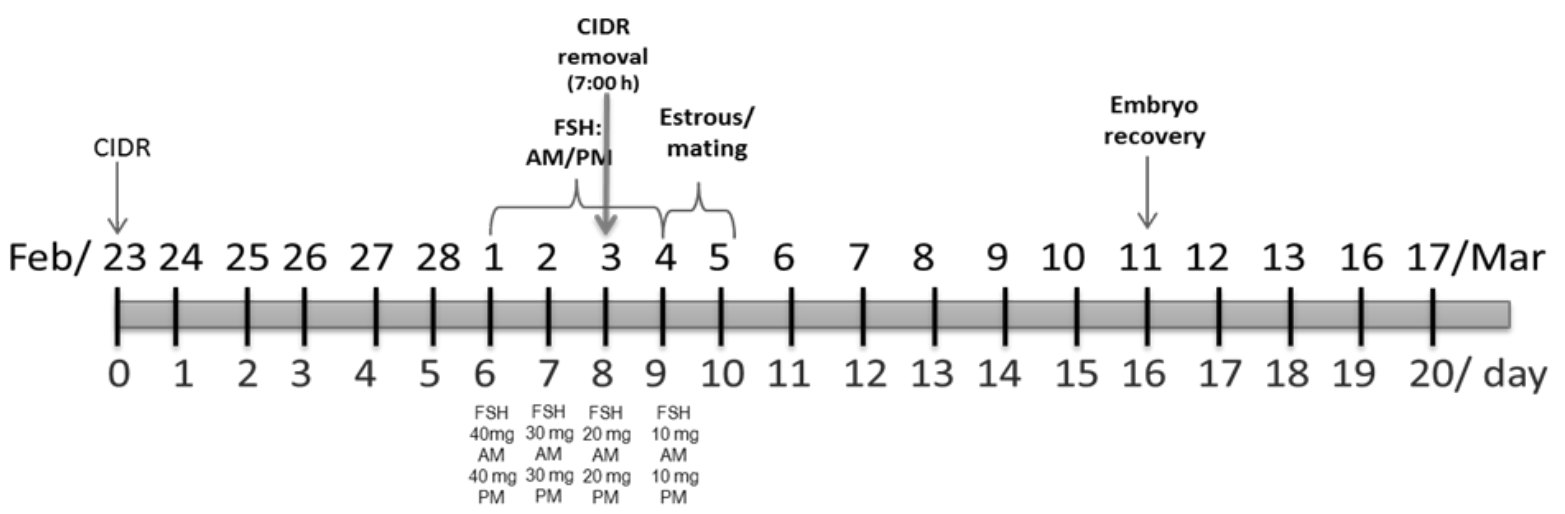

Figure 1 Superovulation protocol and embryo recovery in ewes at decreasing doses of follicle-stimulating hormone. 
The oestrous behaviour was monitored twice a day (7:00 and 18:00) with $1 \mathrm{~h}$ observation period, starting 18 hours after the removal of the intravaginal progesterone-releasing devices. A targeted mating was performed with fertile rams with two copulas at $12 \mathrm{~h}$ intervals.

To verify the superovulatory response (SR), a laparoscopic examination was performed with a $5 \mathrm{~mm}$ cannula (laparoscope, IVT). After confirming the response, a midline laparotomy was carried out seven days after mating to expose the uterine horns and recover the embryonic structures. Before this surgical procedure, the animals were sedated with $0.1 \mathrm{mg} 2 \%$ intravenous xylazine (Pisa Agropecuaria, Mexico) per $\mathrm{kg}$ live weight and $5 \mathrm{mg}$ intravenous ketamine (Ketalin, Probiomed, Mexico) per kg live weight The aseptic protocol included a trichotomy, which was performed cranially $1 \mathrm{~cm}$ above the mammary gland, and disinfection with 3\% iodine solution. For local analgesia, a subcutaneous infiltration was carried out over the midline incision with 6 - $8 \mathrm{~mL}$ 2\% lidocaine (Astra Zeneca, Mexico). After placing the surgical drape, a 4-cm incision was made above the udder to expose the uterine horn and record the number of corpus luteum (CL). Recovery of embryos was conducted by puncturing the horns at their base with a $14 G \times 1$ " catheter (Punzocat $^{\circledR}$ ), where a latex-free, one-path $8 \mathrm{Fr}$ urological catheter (ROB-NEL DOVER ${ }^{\mathrm{TM}}$ ) was inserted. A second puncture was made one $\mathrm{cm}$ below the first at the base of the uterine horn, using a $14 \mathrm{G} \times 1$ " catheter (Punzocat $^{\circledR}$ ), through which an endovenous catheter was inserted to apply $50 \mathrm{~mL}$ Hartmann's solution (Laboratorios Pisa, Mexico) to wash each horn twice.

To determine the blood metabolites of total cholesterol, triglycerides, insulin and IGF-1 concentrations, blood samples were obtained on days 0, 7, and 15. After the samples had been taken, blood serum was separated after letting the sample clot and settle down for $30 \mathrm{~min}$ at room temperature, then centrifuged at $3000 \mathrm{rpm}$, aspirated with a digital pipette, placed in Eppendorf $1.5 \mathrm{~mL}$ tubes and stored at $-20{ }^{\circ} \mathrm{C}$ until metabolites and hormones were quantified. Total cholesterol and triglycerides concentrations were determined using an immunosorbent assay at the metabolic chemistry laboratory of the Academic Division of Health Sciences, UJAT. The IGF-1 and insulin concentrations were determined by ELISA, using commercial kits (EIA-4140 and IEA-2935, DRG, Germany) at the animal reproduction laboratory of the Academic Division of Agricultural Sciences of UJAT. A variation coefficient (VC) of $2.6 \%$ and $2.9 \%$ was used during and between assays, respectively, for insulin; and a $6.6 \%$ and $7.7 \%$ VC, during and between essays, respectively, for IGF-1.

The SR percentage was determined based on the number of ewes with super ovulatory response versus the number of ewes per treatment multiplied by 100 . Ovulation rate (OR) was determined through $\mathrm{CL}$ counting on both ovaries. The structures recovered were embryonic and non-embryonic. All embryos recovered were considered for the number of total embryonic structures (TES). These embryos were evaluated and classified on the basis of embryonic development and quality grade in accordance with the criteria set out by the International Society of Embryo Transfers (Wright et al., 2000), where Grades 1 (excellent) and grade 2 (good) corresponded with transferable embryos (TE) and degenerated or nontransferable embryo (DE) belonged to Grades 3 and 4. Fertilization rate (FR) was calculated with this equation: $F R=[T E S /(T E S+U N F)] \times 100$.

Where:

TES $=$ total embryonic structures

UNF = unfertilized oocytes

Recovery rate $(\mathrm{RR})$ was calculated with this ratio: $\mathrm{RR}=[(\mathrm{TES}+\mathrm{NES}) / \mathrm{CL})] \times 100$

NES = total non-embryonic structures

(For non-embryonic structures (NES), unfertilized oocytes and empty pellucid zones were considered)

$\mathrm{CL}=$ number of corpus luteum.

A t-test was used to determine the effect of treatment on the SR, OR, RR, FR, TE and FR variables and other structures (pellucid zone and oocytes), and total embryos, TE and DE using chi-square by PROC FREQ from SAS. The stage of development and quality of embryos were analysed with the PROC CATMOD procedure from SAS. The t-test was carried out for these variables: total cholesterol, triglycerides, insulin and IGF-1 using the same statistical procedure.

\section{Results}

The average SR of ewes was 75\%. No statistical differences were observed in SR between the PO levels (Table 1). The average RR rate was 85\%, with an average OR of 9.33 CLs per ewe. No significant differences were observed between PO3 and PO6. The FR was $82.2 \%$, without statistical differences between treatments.

The average number of recovered structures (embryos, oocytes, and pellucid zone) was 7.87, with no differences between treatments (Table 2). The number of structures classified under other categories (pellucid zone and oocytes) were similar between treatments. The average number of TE (qualities grades 1 
and 2) was $2.86 \pm 0.74$, without significant differences between treatments. However, a lower number of DE $(P<0.04)$ was observed in ewes supplemented with $6 \%$ PO.

Table 1 Means \pm SE of superovulatory response in Katahdin ewes supplemented with $3 \%$ (PO3) and $6 \%$ (PO6) palm oil

\begin{tabular}{lccccc}
\hline \multirow{2}{*}{ Variables evaluated } & \multicolumn{2}{c}{ PO3 } & \multicolumn{2}{c}{ PO6 } & \multirow{2}{*}{$\boldsymbol{P}$-value } \\
\cline { 2 - 4 } & Mean & $\mathbf{\pm S E}$ & Mean & $\mathbf{\pm}$ SE & - \\
Number of ewes & 10 & & 10 & & 0.60 \\
Superovulatory response (\%) & $80.0(8)$ & 12.65 & $70.0(7)$ & 14.49 & 0.41 \\
Ovulation rate (number of CL) & 9.00 & 1.60 & 9.71 & 1.21 & 0.81 \\
Recovery rate (\%) & 85.8 & 12.03 & 84.3 & 11.58 & 0.51 \\
Fertilization rate (\%) & 86.2 & 12.38 & 77.7 & 10.03 & \\
\hline
\end{tabular}

SE: standard error; CL: corpus luteum; PO: palm oil.

Table 2 Means \pm SE of embryonic classification in Katahdin ewes supplemented with 3\% (PO3) or 6\% (PO6) of palm oil

\begin{tabular}{|c|c|c|c|c|c|}
\hline \multirow{2}{*}{ Variables evaluated } & \multicolumn{2}{|c|}{ PO3 } & \multicolumn{2}{|c|}{ PO6 } & \multirow{2}{*}{$P$-value } \\
\hline & Mean & $\pm \mathrm{SE}$ & Mean & $\pm \mathrm{SE}$ & \\
\hline Number of ewes & 8 & - & 7 & - & - \\
\hline Recovered structures & 7.75 & 2.01 & 8.00 & 1.51 & 0.41 \\
\hline Total embryos & 6.12 & 1.78 & 5.57 & 1.64 & 0.73 \\
\hline $\begin{array}{l}\text { Transferable embryos (quality } \\
\text { grades } 1 \text { and } 2)^{\star}\end{array}$ & 2.87 & 0.78 & 2.85 & 1.38 & 0.99 \\
\hline Degenerate embryos & 3.25 & 1.95 & 2.29 & 0.87 & 0.04 \\
\hline Other structures & 2.00 & 1.08 & 1.67 & 0.76 & 0.28 \\
\hline
\end{tabular}

SE: standard error; PO: palm oil. *Quality grade 1 (excellent) and Quality grade 2 (good).

Table 3 Embryonic structures according to stage of development and quality grade in Katahdin ewes supplemented with 3\% (PO3) and 6\% (PO6) palm oil

\begin{tabular}{lccc}
\hline \multirow{2}{*}{ Embryonic classification } & PO3 & PO6 & P-value \\
\cline { 2 - 4 } & Structures observed & Structures observed & 0.07 \\
Development stage 5* & 11 & 8 & 0.07 \\
Development stage 6 & 6 & 8 & $<0.001$ \\
Development stage 7 & 1 & 7 & 0.005 \\
Other development stage & 13 & 1 & 0.05 \\
Quality 1** & 8 & 14 & 0.34 \\
Quality 2** & 10 & 6 & 0.01 \\
Quality 3 and 4** & 14 & 4 & \\
\hline
\end{tabular}

PO: palm oil.

* Development stage: 5 = early blastocyst; 6 = blastocyst; 7 = expanded blastocyst.

${ }^{\star *}$ Quality: 1 = excellent and good embryos; 2 = average embryos; 3 = poor embryos; 4 = degenerated embryos. 
An analysis by developmental stage showed that most of the embryos from ewes supplemented with $6 \%$ PO displayed (Table 3) a trend towards blastocysts $(P=0.07$ ) and expanded blastocysts $(P<0.001)$, versus the ewes supplemented with $3 \% \mathrm{PO}$, where there was a trend towards a greater number of early blastocyst stages $(P=0.07)$ and other lower developmental stage $(P<0.05)$. The ewes supplemented with $6 \%$ PO showed greater numbers $(P=0.05)$ of embryos classified under quality 1 (excellent and good), and a lower number $(P=0.01)$ classified under qualities 3 and 4 (poor and degenerated).

No statistical differences were found in the concentrations of cholesterol, triglycerides, insulin and IGF metabolites between ewes supplemented with 3\% and 6\% PO (Table 4). Hence, there is no conclusive evidence that shows a relationship between the SR and the quality of embryos.

Table 4 Means \pm SE of cholesterol, triglyceride, insulin and insulin-like growth factor-1 concentrations in Katahdin ewes supplemented with 3\% (PO3) and 6\% (PO6) palm oil

\begin{tabular}{lcccc}
\hline Treatment & $\begin{array}{c}\text { COL } \\
(\mathbf{m g} / \mathbf{d L})\end{array}$ & $\begin{array}{c}\text { TRIG } \\
(\mathbf{m g} / \mathbf{d L})\end{array}$ & $\begin{array}{c}\text { INSUL } \\
(\mathbf{n g} / \mathbf{m L})\end{array}$ & $\begin{array}{c}\text { IGF-1 } \\
(\mathbf{n g} / \mathbf{m L})\end{array}$ \\
\hline & & & & \\
PO3 & $85.57 \pm 9.34$ & $29.83 \pm 8.53$ & $0.57 \pm 0.08$ & $182.28 \pm 15.02$ \\
PO6 & $80.04 \pm 7.69$ & $40.43 \pm 9.68$ & $0.40 \pm 0.07$ & $189.55 \pm 21.16$
\end{tabular}

a, b Different literals between rows are statistically different $(P<0.05)$.

COL: cholesterol; TRIG: triglyceride, INSUL; IGF-1: insulin-like growth factor-1.

\section{Discussion}

Multiple ovulation and embryo transference procedures have been applied in sheep and other species as successful tools to enhance genetic progress by promoting the progeny multiplication of genetically superior animals and to preserve genetic material (Bari et al., 1999; Mayorga et al., 2011; Bruno-Galarraga et al., 2014).

The results achieved in SR and OR, and structures and embryos recovered in this study (out-ofseason breeding) were comparable with those reported by Bettencourt et al. (2008) in Black Merino ewes. In spring, these authors reported an SR of $68.8 \%$ with ovulation, fertilization and recovery rates of $12.5 \%$, $92.7 \%$ and $80 \%$, respectively. However, the number of freezable embryos was 8.3 , a greater number than the number of TES obtained in this study.

It has been reported that the SR in donor females is determined by the hormone treatment (Mayorga et al., 2011), the number of TE (Bruno-Galarraga et al., 2014), the season of year (McEvoy et al., 1998; Forcada et al., 2006; Bettencour et al., 2008), and nutritional effects, such as the inclusion of fats in the diet (Huang et al., 2009). These factors are related directly or indirectly to fertilization and recovery rate (RR) (Mayorga et al., 2011).

The results are similar to those reported by Bari et al. (1999), with an average of 8.6 to 10.0 TES per ewe, an OR between 9.5 and 11.7 CLs, an SR between 65.6\% and $72.9 \%$, and an FR between $75.2 \%$ and $82.0 \%$. The results in this study were comparable with those reported by Mayorga et al. (2011), with OR, RR and FR of $7.0 \mathrm{CLs}, 80 \%$ and $80 \%$, respectively, using intravaginal sponges with 40 mg flurogestone acetate.

In terms of the quality of embryos associated with dietary fat supplementation, the types of fatty acids and the energy levels in the diet could have a positive impact on the reproductive aspects of ewes (FouladiNashta et al., 2009). The results of this study show positive effects of PO addition in a ratio of $6 \%$ in ewes, because a lower number of DE was observed, together with a greater number of embryos of excellent or good quality, and hence a lower number of poor or DE.

These results are supported by the studies of several authors in which various sources of fat and their fatty acids were evaluated (Wonnacot et al., 2010; Herrera Camacho et al., 2011). Zeron et al. (2002) by administering fish oil in calcium soap to sheep, found better quality oocytes and membrane integrity in relation to a greater ratio of fatty acids in plasma, follicular liquid and cumulus cells, which match the results of Morei et al. (2009, 2010). Meza-Villalvazo et al. (2013) observed a greater ratio (77.5\%) of oocytes classified under excellent or good quality in sheep supplemented with $3 \%$ and $6 \%$ corn oil versus sheep that did not receive corn oil (46\%). In addition, the ratios of regular and poor-quality oocytes increased in sheep that that did not receive corn oil (56\%), compared with those that received $3 \%$ and $6 \%$ corn oil.

The addition of dietary fat improves not only the quantity and quality of oocytes, but also early embryonic environment and development (Ashworth et al., 2009; Hughes et al., 2011). Uniformity in the early embryonic developmental stage is related to the time of service and the day on which the embryo recovery is 
performed. However, the differences found in this study for more uniform embryonic development in developmental stages 6 and 7 (blastocyst and expanded blastocyst) in ewes supplemented with 6\% PO may be associated with the positive effect of PUFAs (omega 3 and 6) (Akbarinejad et al., 2012) in PO on ovarian and uterine environment, which favours follicular development, fertilization, embryonic development and viability, all of which are consistent with the improvement of oocyte quality as the PUFA levels are increased (Meza-Villalvazo et al., 2014). It is well known that the provision of PUFAs modifies cell processes positively, including biosynthesis of prostaglandins, steroidogenesis, regulation of transcription factor, maternal immune response and remodelling of uterine tissue (Waters et al., 2012), as was observed by several authors using various sources of PUFAs (Webb et al., 2003; Childs et al., 2008; Waleed et al., 2010; McEvoy et al., 2012).

The inclusion of long-chain n-3-PUFAs probably regulates the expression of a number of genes in the endometrium, which may influence uterine function and, consequently, the survival of embryos (Coyne et al., 2008; 2011), which has been proven through a reduction in the concentration of phospholipase A2, followed by a decrease in genic expression, hence reducing the availability of arachidonic acid for the production of series 2 prostaglandins (Waters et al., 2012).

Steroid hormones are essential in reproductive processes (Manna et al., 2009). In steroidogenesis, the transport of cholesterol inside the mitochondria by the steroidogenic acute regulatory protein (STAR) is a limiting stage in the production of steroid hormones (Manna et al., 2005). Prostaglandin $F_{2 a}\left(P F_{2 a}\right)$ may inhibit the genic expression of STAR in the CL and ovaries in several species (Fiedler et al., 1999). It is known today (Waters et al., 2012) that PUFAs promote an increase in the expression of STAR, which is an indication of a decrease in the luteotropic effect of $\mathrm{PGF}_{2 \alpha}$, favouring the development, survival and reduction of DE (Santos et al., 2008).

In these metabolic processes, lipids, glucose, IGF-1 and insulin act in a coordinated and synergic fashion with gonadotropins in folliculogenesis (Webb et al., 1999). Childs et al. (2008) reported that supplementation with n-3-PUFA leads to an increase in the concentrations of COL and systemic IGF-1 and a decrease in the number of DE in heifers. This agrees with the results of this study, in which lower levels of COL and higher levels of IGF-1 were observed in the ewes supplemented with PO6, with no statistical differences with regard to $\mathrm{PO}$, probably because of the similarity in the provision of fatty acids between the two treatments, which prevented finding any differences.

The similarity between the levels of insulin in animals of the two treatment groups is probably because fatty acids of the same source were provided to both groups. In this sense, Espinoza et al. (2008) compared the dietary supplementation of sheep with fats from different sources, diets with no additional fat, and those with calcium soap and bovine fat, and reported higher levels of insulin in the animals that consumed bovine fat, since the monounsaturated fatty acids (oleic) increased the level of rumen propionate, thus influencing the level of insulin (Sano et al., 1995; Espinoza et al., 2008).

\section{Conclusions}

In ewes supplemented with $6 \% \mathrm{PO}$, a higher number of embryos were recovered with more homogeneous developmental stage and better quality. Supplementation with PO in the preparation of donor ewes may be a recommendable practice contributing to an improvement in the quality of embryos, but not to ovulatory response and embryo yield.

\section{Acknowledgements}

The authors wish to acknowledge the Faculty Improvement Programme (PROMEP) for financing project UJATCA-221, as well as H. Pérez for donating the ewes for this experiment.

\section{Authors' Contributions}

STZ was an undergraduate student in the project. CLP, JAAC, JAPT and RJAL were in charge of project design and project implementation. All co-authors participated in collating the results, carrying out statistical analyses, interpreting the study, writing and correcting the manuscript.

\section{Conflict of Interest Declaration}

The authors declare that they have no conflicts of interest. They also confirm that this manuscript has been read and approved by all authors and that the order of authors listed in the manuscript has been approved by all of them.

\section{References}

Akbarinejad, V., Niasari-Naslaji, A., Mahmoudzadeh, H. \& Mohajer, M., 2012. Effects of diets enriched in different sources of fatty acids on reproductive performance of Zel sheep. Iran. J. Vet. Res. 13, 310-316.

Ashworth, C.J., Toma, L.M. \& Hunter, M.G., 2009. Nutritional effects on oocyte and embryo development in mammals: implications for reproductive efficiency and environmental sustainability. Philos. Trans. R. Soc. Lond. B. Biol. Sci. 364, 3351-3361. 
Bari, F., Khalid, M., Haresign, W., Murray, A. \& Merre, B., 1999. Effect of mating system, flushing procedure, progesterone dose and donor ewe age on the yield and quality of embryos within a MOET program in sheep. Theriogenol. 52, 727-742.

Bettencourt, E.M., Bettencourt, C.M., Chagas e Silva, J., Ferreira, P., Manito, C.I., Matos, C.M., Romao, R.J. \& Rocha, A., 2008. Effect of season and gonadotrophin preparation on superovulatory response and embryo quality in Portuguese Black Merinos. Small Rumin. Res. 74, 134-139.

Boland, M.P., Lonergan, P. \& Callaghan, D.O., 2001. Effect of nutrition on endocrine parameters, ovarian physiology, and embryos development. Theriogenol. 55, 1323-1340.

Bruno-Galarraga, M.M., Cueto, M., Gibbons, A.E., Pereyra-Bonnet, F., Catalano, R. \& Gonzalez-Bulnes, A., 2014. Repeatability of superovulatory response to successive FSH treatments in Merino sheep. Small Rumin. Res. 120, 84-89.

Childs, S., Hennessy, A.A., Sreenan, J.M., Wathes, D.C., Cheng, Z., Stanton, C., Diskin, M.G. \& Kenny, D.A., 2008. Effect of level of dietary n-3 polyunsaturated fatty acid supplementation on systemic and tissue fatty acid concentrations and on selected reproductive variables in cattle. Theriogenol. 70, 595-611.

Coyne, G.S., Kenny, D.A., Childs, S., Sreenan, J.M. \& Waters, S.M., 2008. Dietary n-3 polyunsaturated fatty acids alter the expression of genes involved in prostaglandin biosynthesis in the bovine uterus. Theriogenol. 70, 772-782.

Coyne, G.S., Kenny, D.A. \& Waters, S.M., 2011. Effect of dietary n-3 polyunsaturated fatty acid supplementation on bovine uterine endometrial and hepatic gene expression of the insulin-like growth factor system. Theriogenol. 75 , $500-512$

Espinoza, J.L., Palacios, A., Ortega, R. \& Guillén, A., 2008. Effect of fat supplementation on serum concentrations of progesterone, insulin, growth hormone and some lipid metabolites in Pelibuey ewes. Arch. Med. Vet. 40, 135-140.

Fiedler, E.P., Plouffe Jr., L., Hales, D.B., Hales, K.H. \& Khan, I., 1999. Prostaglandin F (2 alpha) induces a rapid decline in progesterone production and steroidogenic acute regulatory protein expression in isolated rat corpus luteum without altering messenger ribonucleic acid expression. Biol. Reprod. 61, 643-650.

Fouladi-Nashta, A.A., Wonnacott, K.E., Gutierrez, G.C., Gong, J.G., Sinclair, K.D., Garnsworthy, P.C. \& Webb, R., 2009. Oocyte quality in lactating dairy cows fed on high levels of n-3 and n-6 fatty acids. Reprod. 138, 771-781.

Garcia, E., 2004. Modifications to the System Köppen climate classification. 5th ed. Book series number 6 . Institute of Geography, Universidad Nacional Autónoma de México. p. 51. (in Spanish).

Ghaffarilaleh, V., Fouladi-Nashta, A. \& Paramio, M.T., 2014. Effect of a-linolenic acid on oocyte maturation and embryo development of prepubertal sheep oocytes. Theriogenol. 82, 686-696.

Gwazdauskas, F.C., Kendrick, K.W., Pryor, A.W. \& Bailey, T.L., 2000. Impact of follicular aspiration on folliculogenesis as influenced by dietary energy and stage of lactation. Symposium: Folliculogenesis in the Bovine Ovary. J. Dairy Sci. 83, 1625-1634.

Herrera-Camacho, J., Ake-Lopez, R., Ku-Vera, J.C., Williams, G.L. \& Quintal-Franco, J.A., 2008. Ovulatory response and embryo quality and development in superovulated Pelibuey ewes supplemented with polyunsaturated fatty acids in the diet. Tec. Pecu. Mex. 46, 107-117.

Herrera-Camacho, J., Soberano-Martínez, A., Orozco-Duran, K.E., Aguilar-Pérez, C. \& Ku-Vera, J.C., 2011. Effect of fatty acids on reproductive performance of ruminants, artificial insemination in farm animals. Ed: Manafi, M., ISBN: 978-953-307-312-5, In: Tech, DOI: 10.5772/16938. Available from: http://www.intechopen.com/books/artificial-insemination-in-farm-animals/effect-of-fatty-acids-on-reproductiveperformance-of-ruminants.

Huang, Y., Schoonmaker, J.P., Oren, S.L., Trenkle, A. \& Beitz, D.C., 2009. Calcium salts of CLA improve availability of dietary CLA. Livest. Sci. 122, 1-7.

Hughes, J., Kwong, W.Y., Li, D. \& Salter, A.M., 2011. Effects of omega-3 and -6 polyunsaturated fatty acids on ovine follicular cell steroidogenesis, embryo development and molecular markers of fatty acid metabolism. Reprod. 141, 105-118.

INEGI, 2010. National Institute of Statistics, Geography and Informatics. México. Available in: http://www.beta.inegi.org.mx/app/mapa/espacioydatos/

Manna, P.R. \& Stocco, D.M., 2005. Regulation of the steroidogenic acute regulatory protein expression: functional and physiological consequences. Curr Drug Targets Immune. Endocr. Metabol. Disord. 5, 93-108.

Manna, P.R., Dyson, M.T. \& Stocco, D.M., 2009. Regulation of the steroidogenic acute regulatory protein gene expression: present and future perspectives. Mol. Hum. Reprod. 15, 321-333.

Marei, W.F., Wathes, D.C. \& Fouladi-Nashta, A.A., 2009. The effect of linolenic acid on bovine oocyte maturation and development. Biol. Reprod. 81, 1064-1072.

Marei, F.W., Wathes, D.C. \& Fouladi-Nashta, A.A., 2010. Impact of linoleic acid on bovine oocyte maturation and embryo development. Reprod. 139, 979-988.

Mattos, R., Staples, C.R. \& Thatcher, W.W., 2000. Effects of dietary fatty acids on reproduction in ruminants. Rev Reprod. 5, 38-45.

Mayorga, I., Mara, L., Sanna, D., Stelletta, C., Morgante, M., Casu, S. \& Dattena, M., 2011. Good quality sheep embryos produced by superovulation treatment without the use of progesterone devices. Theriogenol. 75, 1661-1668.

Meza-Villalvazo, V., Magaña, H., Sandoval, C., Morales, M., Chay, A. \& Trejo, A., 2013. Effect of polyunsaturated fatty acids on follicular population and oocyte quality in Pelibuey sheep. Universidad y Ciencia. 29, 255-261.

Meza-Villalvazo, V., Trejo Córdova, A., Magaña Sevilla, H., Sandoval Castro, C., Chay-Canul, A., Cavazos Garduño, A. \& Martínez-Sánchez, C., 2014. Metabolic profile of conjugated linoleic acid isomers and oocyte quality in hair ewes. Nova Scientia 6, 287-303. 
McEvoy, T.G., Onal, A.G., Speake, B.K. \& Robinson, J.J., 2012. Impact of contrasting fish oil concentrations in the diet on ovine embryo development in vivo and of corresponding diet-specific derivative sera during in vitro culture. J. Anim. Feed Sci. 21, 31-48.

NRC, 1985. National Research Council. Nutrient Requirements of Sheep, Sixth Revised Edition. National Academy Press, Washington D.C., USA.

Renaville, B., Bacciu, N., Comin, A., Motta, M., Poli, I., Vanini, G. \& Prandi, A., 2010. Plasma and follicular fluid fatty acid profiles in dairy cows. Reprod. Dom. Anim. 45, 118-121.

Sano, H., Hayakawa, S., Takahashi, H. \& Terashima, Y., 1995. Plasma insulin and glucagon responses to propionate infusion into femoral and mesenteric veins in sheep. J. Anim. Sci. 73, 191-197.

Santos, J.E.P., Bilby, T.R., Thatcher, W.W., Staples, C.R. \& Silvestre, F.T., 2008. Long chain fatty acids of diet as factors influencing reproduction in cattle. Reproduction in Domestic Animals 43, Suppl. 2, 23-30.

SAS, 2000. Statistical Analysis System. SAS Institute, Cary, N.C. USA.

Trujillo-Castillo, L.F., Velázquez-Martínez, J.R., Medina-Juárez, L.A., Esparza-Rivera, J.R. \& Meza-Velázquez, J.A., 2010. Properties of crude palm oil. In: African Palm in Tabasco. Eds: Velázquez Martínez, J.R. \& Gómez Vázquez, A., Colección José, N., Rovirosa. México. p. 113. (in Spanish).

Velázquez-Martínez, J.R. \& Gómez Vázquez, A., 2010. African palm in Tabasco. Velázquez Martínez, J.R. \& Gómez Vázquez, A., Colección José N. Rovirosa. México. p. 228. (in Spanish).

Waleed, F.M., Claire-Whates, D. \& Fouladi-Nashta, A.A., 2010. The effect of linoleic acid on bovine oocyte maturation and development. Reprod. 13, 979-988.

Waters, S.M., Coyne, G.S., Kenny, D.A., MacHugh, D.E. \& Morris, D.G., 2012. Dietary n-3 polyunsaturated fatty acid supplementation alters the expression of genes involved in the control of fertility in the bovine uterine endometrium. Physiol. Genomics 44, 878-888.

Wathes, D.C., Abayasekara, D.R.E. \& Aitken, R.J., 2007. Polyunsaturated fatty acids in male and female reproduction. Biol. Reprod. 77, 190-201.

Webb, R., Campbell, B.K., Gorverick, H.A., Gong, J.G., Gutierrez, C.G. \& Armstrong, D.G., 1999. Molecular mechanism regulating follicular recruitment and selection. J. Reprod. Fert. Suppl. 54, 33-48.

Wonnacott, K.E., Kwong W.Y., Hughes, J., Salter, A.M., Lea, R.G., Garnsworthy, P.C., Sinclair Webb, R., Nicholas, B., Gong, J.G., Campbell, B.K., Gutierrez, C.G., Garverick, H.A. \& Armstrong, D.G., 2003. Mechanisms regulating follicular development and selection of the dominant follicle. Reprod. Suppl. 61, 71-90.

Wonnacott, K.E., Kwong, W.Y., Hughes, J., Salter, A.M., Lea, R.G., Garnsworthy, P.C. \& Sinclair, K.D., 2010. Dietary omega-3 and -6 polyunsaturated fatty acids affect the composition and development of sheep granulosa cells, oocytes and embryos. Reprod. 139, 57-69.

Wright, J., Andrzej, B., Brock, K., Evans, B., Hare, W., Humbolt, P., Mapletoft, R., Le Guienne, B. \& Nelson, R., 2000. Manual of the International Society of Embryo Transfer. IETS.Org, Pubs. http://www.eits.org/pubs_educational.asp. Accessed: January 4, 2014.

Zeron, Y., Sklan, D. \& Arav, A., 2002. Effect of polyunsaturated fatty acid supplementation on biophysical parameters and chilling sensitivity of ewe oocytes. Mol. Reprod. Develop. 61, 271-278. 